\title{
STUDY OF THE CONCEPTS OF SOCIAL AND ECONOMIC SECURITY OF THE REPUBLIC OF BELARUS
}

\author{
CShvaiba D., ORCID: 0000-0001-6783-9765, Ph.D., Belarusian Trade Union of Workers \\ of Chemical, Mining and oil Industries; Belarusian National Technical University, \\ Minsk,Belarus,shvabia@tut.by
}

\section{ИССЛЕДОВАНИЕ КОНЦЕПЦИЙ ОБЕСПЕЧЕНИЯ СОЦИАЛЬНО-ЭКОНОМИЧЕСКОЙ БЕЗОПАСНОСТИ РЕСПУБЛИКИ БЕЛАРУСЬ}

\begin{abstract}
СШвайба Д. Н., ORCID: 0000-0001-6783-9765, канд. экон. наук, Белорусский профсоюз работников химической, горной и нефтяной отраслей промышленности; Белорусский национальный технический университет, г. Минск, Беларусь, shvabia@tut.by
\end{abstract}

Abstract. In recent years, the financial and economic recovery increasingly rests on the problems of development of the transport network and energy. The measures are taken in recent years, including the reform of monopolies, have not led to a significant increase in investment in these segments of the economy. To some extent, this is due to the lack of institutional criteria to ensure the openness of their work, as well as control over the effective expenditure of funds. In order to resolve these tasks, the Government of the Republic of Belarus will implement measures aimed at the subsequent implementation of institutional reforms and stimulating the pace of financial and economic recovery. We need urgent measures aimed at improving the institutional system, including the creation of accurate and clear 'rules of the game' for all subjects, ensuring an increase in the confidence of all subjects of financial, economic and political activity in the Belarusian society. The previously mentioned instruments of the mechanism of ensuring the socioeconomic security of Belarus form a strong base for the continuation of sustainable development for the long term. In addition, in order to stimulate financial and economic growth, it is necessary to implement tax policy, which is obliged to promote the increase of competitiveness and the rise of business activity of economic entities, as well as to guarantee the reduction of the tax burden for business, including reduction of the value added tax rate in the medium term, simplification of procedures for calculation and payment of taxes and streamlining of tax audits and reporting.

Аннотащия. В последнее время финансово-экономический подъем все более упирается в проблемы развитости транспортной сети и энергетики. Принятые за последние годы меры, в т. ч. по реформированию монополий, не привели к существенному наращиванию инвестиций в обозначенные сегменты экономики. В некоторой степени это связано с отсутствием институциональных критериев, обеспечивающих открытость их работы, а также контроль за результативным расходованием средств. С целью разрешения обозначенных задач Правительство Республики Беларусь станет осуществлять меры, нацеленные на последующее воплощение институциональных преобразований и стимулирование темпов финансово-экономического подъема. Нужны неотложные меры, нацеленные на улучшение институциональной системы, в том числе создание точных и понятных «правил игры» для всех субъектов, обеспечивающих увеличение в белорусском обществе показателя доверия 
всех субъектов финансово-экономической и политической деятельности. Обозначенные ранее инструменты механизма обеспечивания социально-экономической безопасности Беларуси формируют крепкую базу для продолжения стойкого развития на длительную перспективу. Не считая этого, для стимулирования финансово-экономического роста необходимо осуществление налоговой политики, которая обязана содействовать увеличению конкурентоспособности и подъему бизнес-активности субъектов экономики, а также гарантировать понижение для бизнеса налоговой нагрузки, в т. ч. понижение в среднесрочной перспективе ставки налога на добавленную стоимость, упрощение процедур расчетов и уплаты налогов и упорядочение налоговых проверок и отчетности.

Keywords: socio-economic security, government, society, enterprise, employee, threat, security, interests, economics, analysis, system.

Ключевые слова: социально-экономическая защищенность, государство, общество, предприятие, работник, угроза, защищенность, интересы, экономика, анализ, система.

The design of the Belarusian economy is characterized by a low share of production of small and medium-sized businesses in the gross domestic product. A significant proportion of small businesses remain 'in the shadows' without registering and paying taxes.

The lack of effective links between science and the production process does not present an opportunity for the Belarusian economy to compete effectively in the super-technological sectors of the economy-sectors with a higher level of added value. Implementation of scientific achievements in production remains at a low level.

In recent years, the financial and economic recovery is increasingly rests on the problems of development of the transport network and energy. The measures taken in recent years, including the reform of monopolies, have not led to a significant increase in investment in these segments of the economy. To some extent, this is due to the lack of institutional criteria to ensure the openness of their work, as well as control over the effective expenditure of funds.

In order to resolve these tasks, the Government of the Republic of Belarus will implement measures aimed at the subsequent implementation of institutional reforms and stimulating the pace of financial and economic recovery.

We need urgent measures aimed at improving the institutional system, including the creation of accurate and clear 'rules of the game' for all subjects, ensuring an increase in the confidence of all subjects of financial, economic and political activity in the Belarusian society.

The previously mentioned instruments of the mechanism of ensuring the socio-economic security of Belarus form a strong base for the continuation of sustainable development for the long term.

Apart from this, to stimulate financial and economic growth, it is necessary to implement tax policy, which is obliged to promote the increase of competitiveness and the rise of business activity of economic entities, as well as to guarantee the reduction of the tax burden for business, including the reduction in the medium-term value added tax rate, simplification of procedures for the calculation and payment of taxes and the streamlining of tax audits and reporting.

In order to ensure the innovative vector of economic development, it is necessary to implement the creation of ways to promote the protection of intellectual capital rights, the implementation of investment and innovative programs in the ultra-technological sectors of the economy. 
It will be necessary to develop effective measures to support the export of Belarusian products, including the creation of a system of export promotion, similar to that which has developed in the WTO member States.

It is important to activate the customs policy in order to make the most of its regulatory rather than fiscal function.

Special attention of the Government of the Republic of Belarus in the medium term should be paid to the implementation of priority state programs in the field of health care, education, provision of apartments for the population, as well as the formation of the agro-industrial segment.

At the same time, it should be noted that the more developed countries are focusing on the education sector in their own development. According to the materials of the report of the UNESCO Global Education Digest the earth's population spends on education is 2.5 trillion \$. per year, which corresponds to $4,4 \%$ of gross domestic product in the world [1, p. 118]. At the same time, this indicator varies significantly in different States and territories.

Apart from this, we can develop tools aimed at increasing the impact of programmes in the field of public policy and the improvement of means of providing social support. In this regard, it is important to coordinate the work of all authorities engaged in the provision of social support in the implementation of relevant programs, to contribute to the increase of regional and interregional labor mobility.

Financial and economic changes in Belarus put forward to the 1st plan the most difficult difficulties of deep social structural processes, the dynamics of which is determined primarily by qualitative changes in the relations of property, power, in the level of earnings of different strata and groups of the population. It is primarily about employees and employees.

Need continued administrative reform and civil service reform, which focused on providing transparency and regulation of agencies and the consequent reduction in their not right functions.

To provide innovative vector of financial and economic recovery will require an increase in the role of scientific development, transformation of scientific potential in 1 of the leading resources of persistent financial and economic recovery by the method of formation of innovative system, the formation of innovative capital markets, and Advisory services in the innovative sector, improvement of normative legal base of protection of intellectual product, personnel provide innovative economy. It is necessary to create the necessary environment for the introduction of modern technologies in the production process, including the balanced development of innovative infrastructure.

Development territories need to move from ineffective alignment of financial-economic development of territories for the creation of criteria, stimulating the regional actors to mobilize the available resources of the financial-economic recovery. This can be achieved by increasing the effectiveness of public administration, formation and formation of production clusters, improvement of inter-budgetary relations aimed at stimulating reforms in certain areas.

To solve the problems associated with the elimination of infrastructure and technological constraints, it is necessary to develop transport infrastructure as a condition of sustained economic progress, contributing to the rise of goods, the size of information transfer, production capacity, change in the structure of the economy. This task has the opportunity to be successfully solved only with the intensive participation of business.

The formation of competition and the reduction of the non-market segment can be provided by the method of creating and improving market structures, the development of small business, ensuring equal and fair competition. With the General improvement of the business climate and the development of financial and economic incentives for inter-sectoral capital flows, circumstances will be formed to increase the attractiveness of the processing sectors of the economy and services. 
The formation of intellectual capital and an increase in life indicators, modernization of education and health care are considered to be important vectors of the medium-term program to ensure the socio-economic security of Belarus.

At the same time, the solution of medium-term tasks requires a specific strategic concept of ensuring the socio-economic security of Belarus.

Various researchers in recent years have demonstrated the plurality of such concepts and strategies.

We will analyze the main strategic concepts of this kind, which, in General, include all the authoritative scientific trends that have emerged to date.

1st concept. Government concept, which may be called 'the strategy of market reforms in the centralization of state power'. It is often presented as a 'monetary strategy'.

It is officially stated in the program of socio-economic development of the Republic of Belarus until 2020 and other government documents. The government concept is considered to be a continuation of the reforms that have been carried out in Belarus since its inception as an independent country.

The body directly responsible for the development of medium-term and long-term strategies in the government is the Ministry of economy of the Republic of Belarus.

The researchers identify the following main objectives of financial and economic reforms in the medium term:

-implementation of administrative reform in order to increase the effectiveness of public administration;

-the beginning of the reform of the budget sector with the transition to medium-term budget planning;

-diversification of the Belarusian economy in the direction of overcoming its dependence on raw materials;

-increasing the efficiency of health care, including in order to form a multiplier effect for the development of other segments of the economy;

-conclusion of negotiations on accession to the WTO and adoption of the necessary legislative acts;

-formation of the regulatory framework and increase the effectiveness of the financial structures, the continuation of the reform of the banking system;

-clarification of the policy towards the EU as the 1st of the main foreign economic partners of Belarus;

-saving the achieved results: in the political sphere-the preservation of the democratic system, in the financial — the model of the tax system, allowing low taxes on a flat scale and minimizing benefits.

The 2-nd concept is a strategy for the formation of information and industrial economy, which is more clearly stated in the collective monograph of academician L. I. Abalkin Russia's Strategic response to the challenges of the new century [2]. It considers conceptual approaches to the development of socio-economic strategy of the Union state until 2025 from all sides.

The basis of the presented strategy is formed by three key ideological theses: first, confidence in the need for the country's movement to the information-industrial society in the context of globalization processes; second, recognition of the individual and society as the main target subjects of development; third, the formation of the strategic role of the country as a carrier system and 'locomotive', ensuring the movement of the state forward. 
The essence of the presented strategy is to focus on the development of domestic production forces, the creation of information and industrial technologies on the domestic industrial base with their introduction into the real segment of the economy and exports to global markets. As well as the restructuring of the economy from the sale of raw materials and energy to the production of final goods and a significant increase in the volume of the final product of the share of consumer products and services for the population of the state.

According to the authors, the strategy must be implemented in 3 stages:

-The 1st stage is the period of concentration of efforts on overcoming the decline of the main and intellectual capital, as well as the development of the "maximum favored mode" for the development of the super-technological complex;

-Stage 2-the period of completion of the process of modernization and innovation of innovative engineering. Creation of criteria for the progress of humanitarian sectors of the economy: science, education;

-The 3rd stage is the period of minimization of state aid, liberalization of the economy, reduction of customs barriers, reduction of state costs in the real sector of the economy.

The last stage of economic development in this concept is to approach the group of States favorites of the global economy by their own level of technological and social development.

The concept of researchers is embodied in the state policy of socio-economic formation, but some ideas are applied. In the presented concept of strategic formation, considerable attention is paid to the role of the country in investing in the real segment of the economy. In General, it is possible to argue that it tends to Keynesian model out of decline.

The 3rd concept is a public concept of strategic management [3]. One of its founders Is D. S. Lvov, who says that important vectors of reforms can be:

-real care for people in order to modify the unfavorable type of social world formed in the minds of people, and their focus on creative work;

-development and implementation of methods of social control over the government to fulfill its own obligations;

-restoration of the ownership structure as a whole;

-raising the minimum wage to a guaranteed subsistence level and generally creating a more equitable system of social guarantees;

-creation of the state property system, with the possibility of formation of the Fund of future generations and the state dividend Fund;

-to ensure a regular monetary circulation through strictly controlled the credit issue.

The 4th concept - the strategy of spatial formation of academician A. G. Granberg [4, p. 13].

The essence of the concept is the idea that "the economy of the country is not a single object, but a multiregional organism functioning on the basis of vertical (center - regions) and horizontal (interregional) interactions and included in the system of world economic relations. In consequence of this direction of the country is inevitable and the constant search for integrity in the regional diversity, with the growing influence of globalization processes" [4, p. 38].

In the context of the presented concept, the strategy of territorial formation must be a system forming structure of the joint strategy of socio-economic formation of the state. 
The main provisions of the strategy of territorial formation:

-maintenance of important territorial relations in the economy, prevention of unnecessary differentiation of territories by the level of socio-economic formation, harmonious formation of all territories on the basis of their objective specialization, ensuring the effective functioning of the market, consolidation of the unity and security of the country;

-implementation of plans for the development of transcontinental communications passing through the territory of Belarus (railway, road and transcontinental telecommunication systems);

-synthesis of regional strategies into macroregion strategies and a national strategy with simultaneous legal framework.

The economist P. V. Shinkarenko (Russia) adheres to the same concept, believing that in today's conditions it is essential to develop strategic programs for the socio-economic development of large regions. According to the view of P. V. Shinkarenko, the programmatic approach allows to qualify the reference points, in that the territory has the opportunity for a significant use of its advantages [5, p. 140].

The concepts discussed earlier suggest various mechanisms for countering threats to social and economic security. At the same time, they are summarized by the priority allocation of socioeconomic directions of the state formation and the attempt of their detailed development [6-7].

Thus, it is necessary to indicate that the increasing dangers of socio-economic protection of Belarus forms the need to increase the effectiveness of scientifically based counteraction to them, by developing advanced methods of ensuring the socio-economic security of the state.

\section{References:}

1. Zas, S. V. (2011). Natsional'naya bezopasnost' Respubliki Belarus'. Minsk, Belarus. Navuka, 557.

2. Abalkin, L. I. (2004). Strategicheskii otvet Rossii na vyzovy novogo veka. Moscow, Ekzamen, 605.

3. Lvov, D. S. (2002). Kontseptsiya upravleniya natsional'nym imushchestvom. Ekonomicheskaya nauka sovremennoi Rossii, (2), 24.

4. Lvov, S. D. (2004). Strategicheskoe upravlenie: region, gorod, predpriyatie. Moscow, Ekonomika, 602.

5. Shinkarenko, P. V. (2008). Strategicheskoe planirovanie i razvitie predpriyatii. Ekonomicheskaya nauka sovremennoi Rossii, (2), 138-146.

6. Shvaiba, D. (2019). Dynamic regression models of forecasting indicators of social and economic security. Bulletin of Science and Practice, 5(1), 249-257.

7. Shvaiba, D. (2018). Industry of the Republic of Belarus: problems of social and economic security. Bulletin of Science and Practice, 4(9), 245-252.

\section{Список литературы:}

1. Зась С. В. Национальная безопасность Республики Беларусь. Минск: Беларус. навука, $2011.557 \mathrm{c}$.

2. Абалкин Л. И. Стратегический ответ России на вызовы нового века. М.: Экзамен, 2004. $605 \mathrm{c}$.

3. Львов Д. С. Концепция управления национальным имуществом // Экономическая наука современной России. 2002. №2. С. 5-24.

4. Львов С. Д. Стратегическое управление: регион, город, предприятие. М.: Экономика, 2004. 602 c. 
5. Шинкаренко П. В. Стратегическое планирование и развитие предприятий // Экономическая наука современной России. 2008. №2. С. 138-146.

6. Shvaiba D. Dynamic regression models of forecasting indicators of social and economic security // Бюллетень науки и практики. 2019. Т. 5. №1. С. 249-257.

7. Shvaiba D. Industry of the Republic of Belarus: problems of social and economic security // Бюллетень науки и практики. 2018. Т. 4. №9. С. 245-252.

Работа поступила в редакичию 22.06.2019 2.
Принята к публикащии 27.06.2019 2.

Ссылка для цчитирования:

Shvaiba D. Study of the Concepts of Social and Economic Security of the Republic of Belarus // Бюллетень науки и практики. 2019. Т. 5. №8. С. 100-106. https://doi.org/10.33619/2414$2948 / 45 / 11$

Cite as (APA):

Shvaiba, D. (2019). Study of the Concepts of Social and Economic Security of the Republic of Belarus. Bulletin of Science and Practice, 5(8), 100-106. https://doi.org/10.33619/24142948/45/11 